\title{
Clinical characteristics and in-hospital mortality of COVID-19 adult patients in Saudi Arabia
}

\author{
Samah I. Abohamr, MD, FASE, Rami M. Abazid, MD, Mubarak A. Aldossari, MD, PhD, Hala A. Amer, MD, MPH, \\ Omar S. Badhawi, MD, Obaid M. Aljunaidi, MD, Shaimaa H. Alzarzour, Bs. Pharmcy, MPH, Hiba M. Saadeddin, MD, \\ Fayaz A. Bhat, MD, Eman Elsheikh, MD, PhD.
}

\begin{abstract}

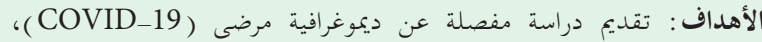

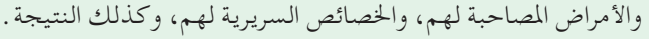

المنهجية: أجريت دراسة مقطعية مستقبلية في مدينة الملك سعود الطبية في

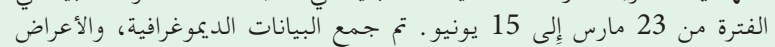

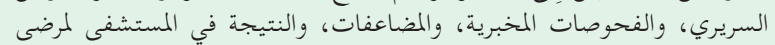

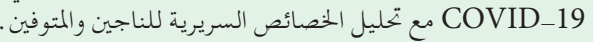

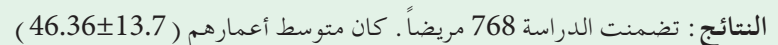

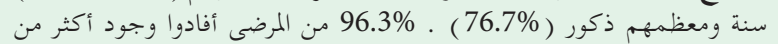

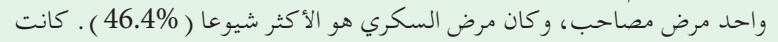

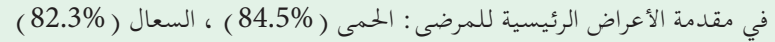

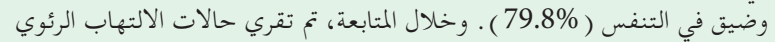

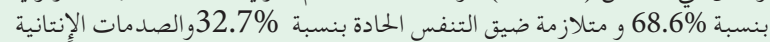

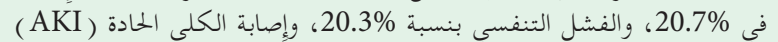

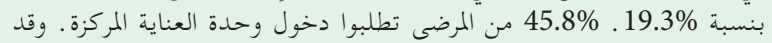

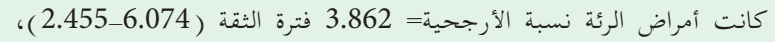

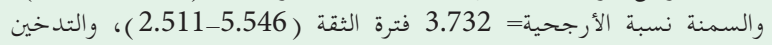

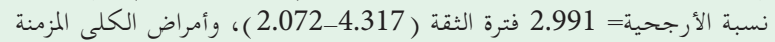

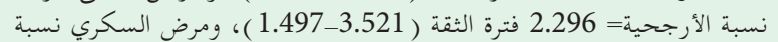

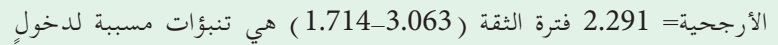

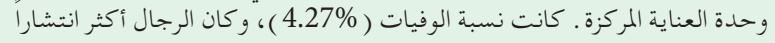

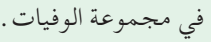

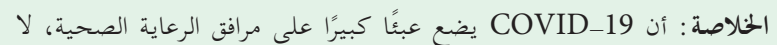

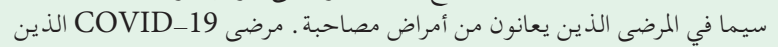

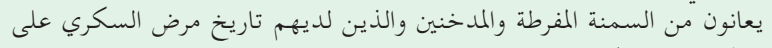

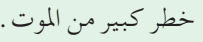

Objectives: To provide a detailed study of demographic, baseline comorbidities, clinical features, and outcome for Coronavirus disease 2019 (COVID-19) patients.

Methods: A record-based case-series study conducted from March 23 to June 15, 2020 in King Saud Medical City, Riyadh, Saudi Arabia. Demographic data, clinical presentation, laboratory investigations, complications, and in-hospital outcome of COVID-19 patients collected with analysis of the clinical characteristics for survivors and deceased.
Results: A total of 768 patients were included. The mean age was $46.36 \pm 13.7$ years and $76.7 \%$ were men. Approximately $96.3 \%$ reported more than one comorbidity; diabetes mellitus was the most frequent $(46.4 \%)$. Fever $(84.5 \%)$, cough $(82.3 \%)$, and shortness of breath $(79.8 \%)$ were the main presenting symptoms. During the follow-up, pneumonia reported in $68.6 \%$, acute respiratory distress syndrome in $32.7 \%$, septic shock in $20.7 \%$, respiratory failure in $20.3 \%$, and acute kidney injury in $19.3 \%$. Approximately $45.8 \%$ of enrolled patients required intensive care unit admission. Lung disease (odd ratio $[\mathrm{OR}]=3.862$ with $95 \%$ confident interval [CI] (2.455-6.074), obesity $(\mathrm{OR}=3.732$, $\mathrm{CI}=2.511-5.546)$, smoking $(\mathrm{OR}=2.991, \quad \mathrm{CI}=2.072-$ 4.317), chronic kidney disease $(\mathrm{OR}=2.296$. $\mathrm{CI}=1.497$ $3.521)$, and diabetes mellitus ( $\mathrm{OR}=2.291, \mathrm{CI}=1.714$ $3.063)$ are predictors of ICU admission. Fatality ratio was $89 / 2084$ (4.27\%). Men were more prevalent in dead group.

Conclusion: Coronavirus disease 2019 places a huge burden on healthcare facilities, particularly in patients with comorbidity. Coronavirus disease 2019 patients who are obese and smokers with history of diabetes mellitus have a high risk of death.

Keywords: COVID-19, in-hospital, clinical characteristics, mortality, Saudi Arabia

Saudi Med J 2020; Vol. 41 (11): 1217-1226 doi: $10.15537 /$ smj.2020.11.25495

From the Heart Health Center (Abohamr, Aldossari, Badhawi, Aljunaidi, Saadeddin, Bhat); from the Department of Prevention and Control of Infection (Amer, Alzarour), King Saud Medical City, Riyadh; from the Internal Medicine Department (Elsheikh), King Faisal University, Alahsa, Kingdom of Saudi Arabia; from Division of Nuclear Medicine, Section of Cardiac Hybrid Imaging, Victoria Hospital, London Health Sciences Centre, London, Ontario, Canada,(Abazid); from the Department of Cardiology (Abohamr, Elsheikh), Tanta University Hospital, Tanta; and from the Community Medicine Department (Amer), National Research Center, Giza, Egypt.

Received 19th August 2020. Accepted 15th October 2020.

Address correspondence and reprint request to: Dr. Eman Elsheikh, Internal Medicine Department, College of Medicine, King Faisal University, Alahsa, Kingdom of Saudi Arabia.E-mail: emancardiology@yahoo.com ORCID ID: https://orcid.org/0000-0002-3150-7125 
$\mathrm{C}$ oronavirus disease 2019 (COVID-19) outbreaks emerged in December 2019 in Wuhan, China. From there it spread rapidly and threaten many different countries in the world, and was soon declared to be a global pandemic. ${ }^{1-4}$ Coronavirus disease 2019 is a highly contagious disease that is caused by the 2019 novel coronavirus (SARS-COV-2) from the Orthocoronavirinae family. The virus contains an enveloped, single-stranded RNA, and distinctive "crown-like" spikes on its surface. ${ }^{5}$ The COVID-19 virus belongs to the same family as the Severe Acute Respiratory Syndrome (SARS-COV) virus, and the Middle East Respiratory Syndrome (MERS-COV) virus. Although it has been reported to be more contagious, its pathogenesis is not fully understood. ${ }^{6,7}$ The most vital encoded structural protein of COVID-19 is the spike glycoprotein $(\mathrm{S})$ that consists of $3 \mathrm{~S} 1-\mathrm{S} 2$ heterodimers that bind to the angiotensin-converting enzyme 2 (ACE2) receptor on type II pneumocytes., ${ }^{2,8}$

In the Kingdom of Saudi Arabia, the first COVID-19 case was declared on March 2, 2020, and most of the confirmed cases were due to returning travelers and their immediate contacts. The total number of COVID-19 confirmed cases, by July 14, 2020, increased to approximately 235,000 , with a fatality rate of approximately $1 \% .^{9,10}$

The manifestations of COVID-19 are broad, usually starting with non-specific symptoms including fever, a dry cough, and fatigue. The disease can also involve a variety of systems, including the respiratory, neurological, musculoskeletal, and the gastrointestinal systems. The disease also can progress rapidly to acute respiratory distress syndrome (ARDS) in highly risk patients such as the elderly, ${ }^{5}$ and individuals with other medical comorbidities such as heart, lung, kidney, or liver diseases. Importantly, patients with immunosuppressive disorders may have worse prognoses and higher mortalities due to the earlier development of septic shock, heart failure, arrhythmias, and multi-organ failure. ${ }^{11-13}$

Information on the clinical characteristics of COVID-19 and its course is rapidly evolving; data are beginning to emerge from retrospective clinical studies conducted worldwide which have focused primarily on epidemiological and clinical characteristics. ${ }^{14,15}$

Disclosure. Authors have no conflict of interests, and the work was not supported or funded by any drug company.
However, there have been few reports conducted in the Middle East region.

The aim of this research is to provide a comprehensive analysis of worst-outcome predictors in addition to demographic, baseline comorbidity, and clinical characteristics of hospitalized COVID-19-positive patients in Saudi Arabia.

Methods. A descriptive, record-based case-series single-center study that included all adult patients confirmed with COVID-19 who were hospitalized in King Saud Medical City, Riyadh, Saudi Arabia between March 23 and June 15, 2020. Exclusion criteria were COVID-19 patients with unavailable or incomplete data.

The process of suspicion-to-confirmation of COVID-19 was guided by the Saudi Centers for Disease Control and Prevention guidelines (updated in June 2020) based on the best available data and evidence. ${ }^{16}$ According to the latest of these guidelines, all patients visiting the emergency department were scored using the Visual Triage Checklist (V1:3, Appendix-I). ${ }^{16}$ Patients with relevant triage scores were directed to a designated respiratory clinic for full assessment for COVID-19/MERS-CoV based on a surveillance case definition (V1:3, Appendix-II). ${ }^{16}$ A nasopharyngeal swab sample was collected for COVID-19 laboratory screening using a polymerase chain reaction (PCR) test. Confirmation of a COVID-19 infection was then reported based on a positive PCR result. Patients with confirmed COVID-19 infections and complete clinical and laboratory data were included in our study.

All demographic data, clinical presentation data (including clinical symptoms and signs), comorbidities, laboratory findings, and outcomes were collected from electronic medical records. The laboratory investigations included the PCR results for SARS-CoV-2 infection, complete blood count, cardiac enzymes (troponin I, creatinine kinase $[\mathrm{CK}], \mathrm{CK}-\mathrm{MB}), \mathrm{D}$-dimer, C-reactive protein, prothrombin time, lactate dehydrogenase, glycated hemoglobin ( $\mathrm{Hb} \mathrm{A} 1 \mathrm{C}$ ), and liver- and renalfunction tests. Clinical outcomes were classified into 3 categories: home-isolation, hospitalization, and death.

In the early stages of this pandemic in Saudi Arabia, hospital admission was mandatory for all suspected cases, and confirmed cases were referred to designated facilities for further follow-up. As the situation evolved, home isolation of suspected and confirmed COVID-19 cases that were clinically stable was allowed if they met certain criteria defined by the Saudi Ministry of Health (Appendix-III). ${ }^{16}$ 
This work was performed in compliance with the ethical approval of the Ethical Committee of the King Saud Medical City and the Helsinki Declaration and its amendments by World Medical Association (WMA).

Statistical analyses. The data were analyzed using Microsoft Excel 2016 and Statistical Package for Social Sciences for Windows, version 26 (IBM Corp., Armonk, NY, USA). Continuous (normally distributed) variables were represented as means \pm SDs with $95 \%$ confidence intervals (CI), and percentiles, frequencies, and percentages were used for categorical variables. Non-normally distributed variables were represented as medians with $25 \%$ and $75 \%$ values. Student's t-tests were used to compare means of normally distributed variables between groups, and the Mann-Whitney $U$ test was used for non-normally distributed variables. The $\chi^{2}$ test, or Fisher's exact test, was used to compare categorical variables between groups. Effect modifications were evaluated by stratification, statistical interaction was assessed by including main predictor variables and their product terms in the binary logistic regression analysis in addition to mutinominal logistic regression analysis. A $p$-value $<0.05$ was considered statistically significant.

Results. Baseline characteristics. During the period of our study, 2084 patients were diagnosed with
COVID-19. A total of 768 patients with full clinical data sets were included in this study (Figure 1).

The mean age was $46.36 \pm 13.7$ years and $76.7 \%$ were male. The dominant nationality among the patients was non-Saudi (75.5\%). Many of the patients (96.3\%) had more than one comorbidity. Diabetes mellitus was the most common $(46.4 \%)$ in patients, followed by hypertension (34.6\%), smoking (20.8\%), obesity (8.6\%), lung disease $(14.1 \%)$ chronic kidney disease (CKD) (13.5\%), history of ischemic heart disease (IHD) (10.7\%), and cerebrovascular accident (CVA) $(5.9 \%)$. Other clinical characteristics are presented in Table 1.

Clinical presentation. Patient clinical presentations were variable. The following symptoms were reported: fever $(84.5 \%)$, cough $(82.3 \%)$, shortness of breath $(79.8 \%)$, and diarrhea (21.9\%). In addition, 39 patients (5.1\%) were diagnosed with acute coronary syndrome (ACS), 32 (4.2\%) presented with decompensated heart failure, $7(0.9 \%)$ presented with arrhythmia, and 2 $(0.3 \%)$ presented with myocarditis. During follow-up, pneumonia was reported in 527 patients (68.6\%), ARDS in 251 (32.7\%), septic shock in 159 (20.7\%), respiratory failure (RF) in $156(20.3 \%)$, and acute kidney injury (AKI) in 148 patients (19.3\%) (Table 1).

Management plan and complications. In total, 590 patients $(76.8 \%)$ were hospitalized due to severe

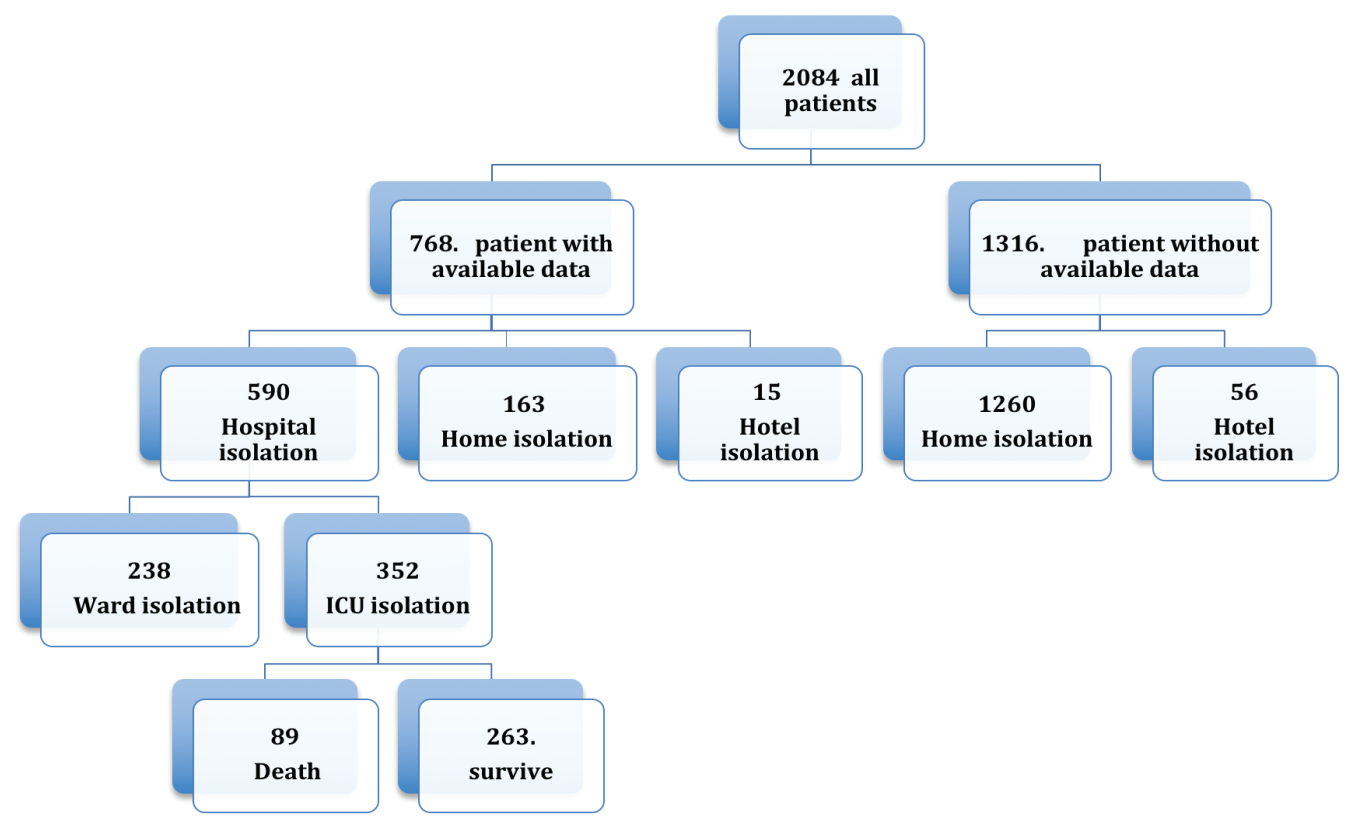

Figure 1 - The flowchart of analysis procedure. 
Table 1 - Demographics and clinical characteristics of patient ( $N=768)$.

\begin{tabular}{|c|c|}
\hline Demographic data & n $(\%)$ \\
\hline $\begin{array}{l}\text { Age (years) } \\
\text { Mean } \pm \text { SD } \\
\text { Min-Max }\end{array}$ & $\begin{array}{c}46.36 \pm 13.7 \\
21.0-75.0\end{array}$ \\
\hline \multicolumn{2}{|l|}{ Gender } \\
\hline Male & $589(76.7)$ \\
\hline Female & $179(23.3)$ \\
\hline \multicolumn{2}{|l|}{ Nationality } \\
\hline Saudi & $188(24.5)$ \\
\hline Non-Saudi & $580(75.5)$ \\
\hline \multicolumn{2}{|l|}{ History of comorbidities: } \\
\hline Smoker & $160(20.8)$ \\
\hline Obesity & $143(18.6)$ \\
\hline Hypertension & $266(34.6)$ \\
\hline Chronic kidney disease & $104(13.5)$ \\
\hline Diabetes Mellitus & $356(46.4)$ \\
\hline Cerebro vascular accidents & $45 \quad(5.9)$ \\
\hline Ischemic heart disease & $82(10.7)$ \\
\hline Lung disease & $108(14.1)$ \\
\hline \multicolumn{2}{|l|}{ Clinical presentation, $n(\%)$ : } \\
\hline Fever & $649(84.5)$ \\
\hline Shortness of breath & $613(79.8)$ \\
\hline Cough & $632(82.3)$ \\
\hline Diarrhea & $168(21.9)$ \\
\hline Heart Failure & $32(4.2)$ \\
\hline Acute coronary syndrome & $39(5.1)$ \\
\hline Myocarditis & $2(0.3)$ \\
\hline Arrhythmia & $7 \quad(0.9)$ \\
\hline \multicolumn{2}{|l|}{ Complications, $n(\%)$ : } \\
\hline Pneumonia & $527(68.6)$ \\
\hline Acute respiratory distress syndrome & $251(32.7)$ \\
\hline Septic shock & $159(20.7)$ \\
\hline Respiratory failure & $156(20.3)$ \\
\hline Acute kidney injury & $148(19.3)$ \\
\hline Death & $89(11.6)$ \\
\hline
\end{tabular}

Values are presented as numbers and percentages (\%).
Table 1 - Demographics and clinical characteristics of patient ( $=768)$ (continuation).

\begin{tabular}{|c|c|}
\hline Demographic data & n $(\%)$ \\
\hline \multicolumn{2}{|l|}{ Laboratory investigations } \\
\hline Hemoglobin $(\mathrm{g} / \mathrm{dl})(\operatorname{mean} \pm \mathrm{SD})$ & $12.3 \pm 2.36$ \\
\hline White blood cells, (10^9/L) (Min-Max) & $9.0(6.1-12.6)$ \\
\hline Leucopenia, (\%) & $261(34.0)$ \\
\hline Platelets, $\left(10^{\wedge} 9 / \mathrm{L}\right)(\operatorname{mean} \pm \mathrm{SD})$ & $265.84 \pm 111.1$ \\
\hline International normalized ratio $($ mean $\pm S D)$ & $1.11 \pm 0.18$ \\
\hline Creatine kinase (U/L) & $245.0(104.3-517.5)$ \\
\hline Lactate dehydrogenase (U/L) (Min-Max) & $495.0(333.2-760.0)$ \\
\hline Creatine kinase-MB (ng/ml) & $1.9(0.6-12.0)$ \\
\hline Cardiac troponin I (ng/mL) (Min-Max) & $0.001(0.001-0.006)$ \\
\hline D-dimer (mg/L) (Min-Max) & $1.1(0.9-2.3)$ \\
\hline Creatinine (mmol/L) (Min-Max) & $87.0(67.0-124.0)$ \\
\hline Urea $(\mathrm{mmol} / \mathrm{L})(\mathrm{Min}-\mathrm{Max})$ & $5.7(4.0-9.0)$ \\
\hline Blood sugar (mmol/L) (Min-Max) & $8.7(6.0-15.0)$ \\
\hline Aspartate aminotransferase (U/L) (Min-Max) & $43.0(27.0-79.0)$ \\
\hline Alanine aminotransferase (U/L) (Min-Max) & $31.0(23.0-50.3)$ \\
\hline Total bilirubin (umol/L) (Min-Max) & $10.69(7.0-17.0)$ \\
\hline Sodium $(\mathrm{mmol} / \mathrm{L})(\operatorname{mean} \pm \mathrm{SD})$ & $138.5 \pm 4.43$ \\
\hline \multicolumn{2}{|l|}{ Isolation status after confirmation } \\
\hline Home isolation & $163(21.2)$ \\
\hline Hotel isolation & $15(2.0)$ \\
\hline Hospital isolation & $590(76.8)$ \\
\hline Ward isolation & $238(31.3)$ \\
\hline Intensive care unit isolation & $352(45.8)$ \\
\hline
\end{tabular}

symptoms either in the intensive care unit (ICU; $352 ; 45.8 \%)$ or on a general ward $(240 ; 31.3 \%)$. In contrast, 163 patients $(21.2 \%)$ with mild symptoms were isolated at home and $15(2.0 \%)$ were isolated in hotels (Table 1). We found that patients admitted to the ICU were significantly older than non-ICU admissions (mean $47.4 \pm 13.8$ years vs $45.5 \pm 13.5$ years, $p=0.05$ ). Males were admitted to the ICU more often than women $(284 ; 80.7 \%$ versus $69 ; 19.3 \%, p=0.01]$.

For other comorbidities, we found that ICU admission was significantly associated with smokers compared to non-smokers $(p=0.001)$, obesity $(p=0.001)$, hypertension $(p=0.01), \mathrm{CKD}(p=0.001)$, diabetes mellitus $(p=0.001)$, IHD $(p=0.03)$, and lung 
disease $(p=0.001)$. Reported complications were also significantly higher among ICU admissions when compared to non-ICU admissions for pneumonia $(p=0.01)$, ARDS $(p=0.001)$, septic shock $(p=0.001)$, RF $(p=0.001)$, AKI $(p=0.001)$, and death $(p=0.01)$. Five patients (1.4\%) with ARDS admitted to the ICU required treatment with extracorporeal membrane oxygenation (Table 2).

Laboratory results. Patients who were admitted to the ICU had significantly lower hemoglobin levels $(p=0.001)$ and platelet counts $(p=0.04)$, but international normalized ratio (INR), creatinine, and D-dimer values were significantly higher in ICU patients. Other laboratory results are presented in Table 2.

Predictors for ICU admission. Using a univariate regression we found that lung disease, obesity, smoking, CKD, and diabetes mellitus were predictors for ICU admission (Table 3).

Predictors for death. During follow-up, 89 patients $(4.27 \%)$ died, with males being more prevalent. Demographic and clinical characteristics of deceased patients compared to survived patients are shown in Table 4.

A univariate regression analysis in Table 5 showed that clinical predictors of death were: obesity $(p=0.001)$, history of smoking $(p=0.001)$, and diabetes mellitus $(p=0.001)$.

Discussion. The present study analyzed the demographics of patients with confirmed COVID-19 infections and found that $76.8 \%$ were hospitalized (45.8\% requiring ICU admission). The mortality rate was approximately $4.3 \%$. Male gender, ARDS, acute renal failure, and septic shock were major predictors for death.

The COVID-19 outbreak in Saudi Arabia is one of the biggest challenges in the last few decades. Although older patients are more vulnerable for infection, younger patients were predominantly affected here with a mean age of 46.4 years; close to that ( 47 years) reported previously for the young adults representing the majority of COVID-19-positive patients. ${ }^{15,17,18}$ Male-gender predominance in our study was also similar to that reported by Huang et al ${ }^{14}$ and Chen et al. ${ }^{19} \mathrm{~A}$ recent report (published May 10, 2020) confirmed that men have higher ACE2 levels than women, and
Table 2 - Demographics and clinical characteristics of patients regarding Non-intensive care unit (ICU) and ICU admission.

\begin{tabular}{|c|c|c|c|}
\hline Demographic data & $\begin{array}{c}\text { Non-ICU } \\
n=416\end{array}$ & $\underset{\mathrm{n}=352}{\mathrm{ICU}}$ & $P$-value \\
\hline Age (years) $($ mean $\pm S D)$ & $45.5 \pm 13.5$ & $47.4 \pm 13.8$ & $0.049^{*}$ \\
\hline \multicolumn{4}{|l|}{ Gender } \\
\hline Female & $111(26.7)$ & $68(19.3)$ & $0.008^{*}$ \\
\hline Male & $305(73.3)$ & $284(80.7)$ & \\
\hline \multicolumn{4}{|l|}{ Nationality } \\
\hline Non-Saudi & $308(74.0)$ & $272(77.3)$ & 0.134 \\
\hline Saudi & $108(26.0)$ & $80(22.7)$ & \\
\hline \multicolumn{4}{|l|}{ History of comorbidities } \\
\hline Smoker & $53(12.7)$ & $107(30.4)$ & $0.001^{*}$ \\
\hline Obesity & $41 \quad(9.9)$ & $102(29.0)$ & $0.001^{*}$ \\
\hline Diarrhea & $103(24.8)$ & $65(18.5)$ & $0.018^{*}$ \\
\hline Hypertension & $125(30.0)$ & $141(40.1)$ & $0.008^{*}$ \\
\hline Chronic kidney disease & $38 \quad(9.1)$ & $66(18.8)$ & $0.001^{*}$ \\
\hline Diabetes mellitus & $154(37.0)$ & $202(57.4)$ & $0.001^{*}$ \\
\hline Cerebro vascular accidents & $26(6.3)$ & $19 \quad(5.4)$ & 0.612 \\
\hline Ischemic heart disease & $35 \quad(8.4)$ & $47(13.4)$ & $0.028^{*}$ \\
\hline Lung disease & $29(7.0)$ & $79(22.4)$ & $0.001^{*}$ \\
\hline \multicolumn{4}{|l|}{ Clinical presentation } \\
\hline Fever & $353(84.9)$ & $296(84.1)$ & 0.701 \\
\hline Shortness of breath & $329(79.1)$ & $284(80.7)$ & 0.587 \\
\hline Cough & $346(83.2)$ & $286(81.3)$ & 0.479 \\
\hline Heart failure & $16(3.8)$ & $16(4.5)$ & 0.602 \\
\hline Acute coronary syndrome & $14 \quad(3.4)$ & $25 \quad(7.1)$ & $0.019^{*}$ \\
\hline Myocarditis & $1 \quad(0.2)$ & $1 \quad(0.3)$ & 0.879 \\
\hline Arrhythmia & $3(0.7)$ & $4 \quad(1.1)$ & 0.489 \\
\hline \multicolumn{4}{|l|}{ Complications } \\
\hline Pneumonia & $270(64.9)$ & $257(73.0)$ & $0.008^{*}$ \\
\hline $\begin{array}{l}\text { Acute respiratory } \\
\text { distress syndrome }\end{array}$ & $34 \quad(8.2)$ & 217 (61.6) & $0.001^{*}$ \\
\hline Septic shock & 11 (2.6) & $148(42.0)$ & $0.001^{*}$ \\
\hline Respiratory failure & $25(6.0)$ & $131(37.2)$ & $0.001^{*}$ \\
\hline Acute kidney injury & $28 \quad(6.7)$ & $120(34.1)$ & $0.001^{*}$ \\
\hline Death rate & $0 \quad(0.0)$ & $89(25.3)$ & $0.001^{*}$ \\
\hline
\end{tabular}

Values are presented as number and percentages (\%). ${ }^{*} p$-value $<0.05$ is significant. 
Table 2 - Demographics and clinical characteristics of patients regarding Non-intensive care unit (ICU) and ICU admission (continuation)

\begin{tabular}{lccc}
\hline Demographic data & $\begin{array}{c}\text { Non-ICU } \\
\mathbf{n}=416\end{array}$ & $\begin{array}{c}\text { ICU } \\
\mathbf{n}=352\end{array}$ & $P$-value \\
\hline Laboratory investigations & & & $0.001^{*}$ \\
Hemoglobin, (g/dl) (mean $\pm \mathrm{SD})$ & $12.6 \pm 2.2$ & $11.9 \pm 2.5$ & $0.001^{*}$ \\
White blood cells, $\left(10^{\wedge} 9 / \mathrm{L}\right)$ & $8.0(6.0-11.7)$ & $9.8(6.5-13.0)$ & 0.211 \\
Leucopenia & $133(32.0)$ & $128(36.4)$ & $0.038^{*}$ \\
Platelets, $\left(10^{\wedge}\right.$ /L) (mean $\left.\pm \mathrm{SD}\right)$ & $273.2 \pm 108.5$ & $257.1 \pm 113.6$ & $0.001^{*}$ \\
International normalized ratio & $1.1 \pm 0.1$ & $1.3 \pm 0.2$ & $0.001^{*}$ \\
Creatine kinase (U/L) & $194.3(95.3-388.7)$ & $298.5(146.5-666.8)$ & $0.001^{*}$ \\
Lactate dehydrogenase (U/L) & $422.5(244.3-659.3)$ & $654.5(429.0-963.0)$ & $0.001^{*}$ \\
Creatine kinase-MB (ng/ml) & $1.3(0.4-9.0)$ & $3.2(1.0-15.0)$ & $0.008^{*}$ \\
Cardiac troponin I (ng/mL) & $0.001(0.001-0.001)$ & $0.001(0.001-0.1)$ & $0.001^{*}$ \\
D-dimer (mg/L) & $1.0(0.7-1.6)$ & $1.5(1.0-3.6)$ & $0.001^{*}$ \\
Creatinine (mmol/L) & $80.0(62.0-100.0)$ & $101.5(78.0-50.3)$ & $0.001^{*}$ \\
Urea (mmol/L) & $5.0(3.7-7.3)$ & $6.7(4.6-12.0)$ & $0.001^{*}$ \\
Blood sugar (mmol/L) & $8.0(5.7-13.0)$ & $10.0(7.0-16.2)$ & $0.001^{*}$ \\
Aspartate aminotransferase (AST) (U/L) & $36.0(24.7-58.0)$ & $55.0(32.0-98.7)$ & $0.009^{*}$ \\
Alanine aminotransferase (ALT) (U/L) & $28.9(22.5-45.0)$ & $32.0(23.0-60.3)$ & $0.001^{*}$ \\
Total bilirubin (umol/L) & $9.4(6.3-15.0)$ & $12.0(8.0-19.0)$ & 0.794 \\
Sodium (mmol/L) & $138.5 \pm 3.9$ & $138.4 \pm 5.0$ & $0.008^{*}$ \\
Extracorporeal membrane oxygenation & $0(0.0)$ & $5(1.4)$ & \\
\hline
\end{tabular}

Values are presented as number and percentages $(\%) .{ }^{*} p$-value $<0.05$ is significant.

Table 3 - Predictors of risk of intensive care unit admission among COVID-19 patients.

\begin{tabular}{|c|c|c|c|}
\hline Predictors & OR & $\begin{array}{c}95 \% \text { CI } \\
\text { Lower - Upper }\end{array}$ & $P$-value \\
\hline \multicolumn{4}{|l|}{ History of comorbidities } \\
\hline Lung disease & 3.862 & $2.455-6.074$ & $0.001^{*}$ \\
\hline Obesity & 3.732 & $2.511-5.546$ & $0.001^{*}$ \\
\hline Smoker & 2.991 & $2.072-4.317$ & $0.001^{*}$ \\
\hline Chronic kidney disease & 2.296 & $1.497-3.521$ & $0.001^{*}$ \\
\hline Diabetes mellitus & 2.291 & $1.714-3.063$ & $0.001^{*}$ \\
\hline \multicolumn{4}{|l|}{ Complications } \\
\hline Septic shock & 26.711 & $14.152-50.415$ & $0.001^{*}$ \\
\hline ARDS & 18.06 & $11.969-27.249$ & $0.001^{*}$ \\
\hline Respiratory failure & 9.271 & $5.861-14.663$ & $0.001^{*}$ \\
\hline Acute kidney injury & 7.167 & $4.605-11.155$ & $0.001^{*}$ \\
\hline $\begin{array}{r}P \text {-value calculated } \\
{ }^{*} p \text {-value }<0.05 \text { is signifi } \\
\text { ARDS: acu }\end{array}$ & $\begin{array}{l}\text { nd on lo } \\
\text { OR: odd } \\
\text { piratory }\end{array}$ & $\begin{array}{l}\text { tic regression ana } \\
\text { tio, CI: confiden } \\
\text { stress syndrome }\end{array}$ & $\begin{array}{l}\text { is. } \\
\text { interval, }\end{array}$ \\
\hline
\end{tabular}

as a consequence of ACE2 helping the virus to infect healthy cells, this may explain why men are more susceptible than women to COVID-19. ${ }^{20}$ Importantly, multiple comorbidities such as hypertension, diabetes, and cardiovascular disease can predispose patients to a severe form of the disease and various complications. ${ }^{21}$ Hypertension and diabetes were the most frequently reported comorbidities among COVID-19 patients by Richardson et $\mathrm{al}^{22}$ and likewise, most of our study population had multiple comorbidities. These risk factors can also affect immune-system responses to this infection; a good example is the influence diabetes can have on viral cell-entry and the body's inflammatory response to the infection. ${ }^{23,24}$

We have reported that fever, cough, and shortness of breath were the most prevalent clinical presentations in approximately $80-85 \%$ of patients; findings that are consistent with previous reports. ${ }^{14,17,19,25,26}$ Less commonly, gastrointestinal symptoms such as diarrhea were noted in one fifth of our study patients, similar to that reported in a multi-center Chinese study. ${ }^{27}$ 
Table 4 - Demographics and clinical characteristics of survived COVID-19 patients compared to deceased patients.

\begin{tabular}{|c|c|c|c|}
\hline Demographic data & $\begin{array}{c}\text { Live } \\
\mathrm{n}=679\end{array}$ & $\begin{array}{c}\text { Death } \\
\mathrm{n}=89\end{array}$ & $P$-value \\
\hline Age (years) $($ mean $\pm S D)$ & $45.9 \pm 14.0$ & $47.6 \pm 15.6$ & 0.298 \\
\hline \multicolumn{4}{|l|}{ Gender (\%) } \\
\hline Female & $167(24.6)$ & $12(13.5)$ & $0.019^{*}$ \\
\hline Male & $512(75.4)$ & $77(86.5)$ & \\
\hline \multicolumn{4}{|l|}{ Nationality (\%) } \\
\hline Non-Saudi & $504(74.2)$ & $76(85.4)$ & $0.018^{*}$ \\
\hline Saudi & $175(25.8)$ & $13(14.6)$ & \\
\hline \multicolumn{4}{|l|}{ History of comorbidities (\%) } \\
\hline Smoker & $109(16.1)$ & $51(57.3)$ & $0.001^{*}$ \\
\hline Obesity & $80(11.8)$ & $63(70.8)$ & $0.001^{*}$ \\
\hline Diarrhea & $157(23.1)$ & $11(12.4)$ & $0.021^{*}$ \\
\hline Hypertension & $232(34.2)$ & $34(38.2)$ & 0.501 \\
\hline Chronic kidney disease & $89(13.1)$ & $15(16.9)$ & 0.287 \\
\hline Diabetes mellitus & $294(43.3)$ & $62(69.7)$ & $0.001^{*}$ \\
\hline Cerebro vascular accidents & $42(6.2)$ & $3(3.4)$ & 0.297 \\
\hline Ischemic heart disease & $74(10.9)$ & $8 \quad(9.0)$ & 0.601 \\
\hline Lung disease & $43 \quad(6.3)$ & $3(3.4)$ & 0.297 \\
\hline \multicolumn{4}{|l|}{ Clinical presentation (\%) } \\
\hline Fever & $576(84.8)$ & $73(82.0)$ & 0.511 \\
\hline Shortness of breath & $542(79.8)$ & $71(79.8)$ & 0.897 \\
\hline Cough & $563(82.9)$ & $69(77.5)$ & 0.198 \\
\hline Heart failure & $28 \quad(4.1)$ & $4 \quad(4.5)$ & 0.789 \\
\hline Acute coronary syndrome & 31 & $8 \quad(9.0)$ & 0.069 \\
\hline Myocarditis & $2 \quad(0.3)$ & $\begin{array}{lll}0 & (0.0)\end{array}$ & 0.598 \\
\hline Arrhythmia & $6 \quad(0.9)$ & $1 \quad(1.1)$ & 0.786 \\
\hline \multicolumn{4}{|l|}{ Complication (\%) } \\
\hline Pneumonia & $477(70.3)$ & $50(56.2)$ & $0.009^{*}$ \\
\hline Acute respiratory distress syndrome & $176(25.9)$ & $75(84.3)$ & $0.001^{*}$ \\
\hline Septic shock & $83(12.2)$ & $76(85.4)$ & $0.001^{*}$ \\
\hline Respiratory failure & $74(10.9)$ & $82(92.1)$ & $0.001^{*}$ \\
\hline Acute kidney injury & $72(10.6)$ & $76(85.4)$ & $0.001^{*}$ \\
\hline \multicolumn{4}{|l|}{ Laboratory investigations } \\
\hline Hemoglobin, $(\mathrm{g} / \mathrm{dl})$ & $12.4 \pm 2.3$ & $11.3 \pm 2.6$ & $0.001^{*}$ \\
\hline White Blood Cells, (10^9/L) & $8.8(6.1-12.3)$ & $10.0(6.4-13.0)$ & $0.01^{*}$ \\
\hline Leucopenia & $238(35.1 \%)$ & $23(25.8 \%)$ & 0.412 \\
\hline Platelets, $\left(10^{\wedge} 9 / \mathrm{L}\right)$ & $270.1 \pm 112.2$ & $233.4 \pm 96.8$ & $0.001^{*}$ \\
\hline INR & $1.1 \pm 0.1$ & $1.2 \pm 0.3$ & 0.123 \\
\hline Creatine kinase (U/L) & $231.4(102.8-477.5)$ & $350.0(147.0-1034.0)$ & $0.001^{*}$ \\
\hline Lactate dehydrogenase (U/L) & $473.0(321.0-740.0)$ & $666.0(453.0-1065.5)$ & $0.001^{*}$ \\
\hline Creatine kinase-MB (ng/ml) & $1.7(0.5-12.0)$ & $5.5(1.0-22.2)$ & $0.001^{*}$ \\
\hline Cardiac troponin I (ng/mL) & $0.001(0.001-0.001)$ & $0.02(0.001-0.345)$ & $0.001^{*}$ \\
\hline $\mathrm{D}$-dimer $(\mathrm{mg} / \mathrm{L})$ & $1.0(0.8-2.0)$ & $2.9(1.1-7.2)$ & $0.001^{*}$ \\
\hline Creatinine $(\mathrm{mmol} / \mathrm{L})$ & $85.0(65.0-112.8)$ & $124.0(86.0-181.5)$ & $0.001^{*}$ \\
\hline Urea $(\mathrm{mmol} / \mathrm{L})$ & $5.3(4.0-8.4)$ & $9.0(5.6-18.9)$ & $0.001^{*}$ \\
\hline Blood sugar (mmol/L) & $8.4(6.0-15.0)$ & $10.0(7.0-15.0)$ & 0.070 \\
\hline Aspartate aminotransferase (U/L) & $40.9(26.0-74.0)$ & $64.0(33.3-99.0)$ & $0.001^{*}$ \\
\hline Alanine aminotransferase (U/L) & $30.0(22.5-49.4)$ & $35.0(25.0-60.0)$ & $0.038^{*}$ \\
\hline Total bilirubin (umol/L) & $10.0(6.8-16.0)$ & $12.6(8.6-23.5)$ & $0.001^{*}$ \\
\hline Sodium $(\mathrm{mmol} / \mathrm{L})($ mean $\pm \mathrm{SD})$ & $138.4 \pm 4.4$ & $139.0 \pm 4.6$ & 0.201 \\
\hline
\end{tabular}


Table 4 - Demographics and clinical characteristics of survived COVID-19 patients compared to deceased patients (continuation).

\begin{tabular}{lrrr}
\hline State of isolation (\%) & & & \\
$\quad$ Isolation status after confirmation & $15(2.2)$ & $0(0.0)$ & $0.001^{*}$ \\
Hotel & $163(24.0)$ & $0(0.0)$ & \\
Home & $501(73.8)$ & $89(100.0)$ & $0.001^{*}$ \\
Hospital & & & \\
Hospital isolation & $238(47.5)$ & $0(0.0)$ & 0.487 \\
Ward & $263(52.5)$ & $89(100.0)$ & $1(1.1)$ \\
Intensive care unit & $4(0.6)$ & & \\
Extracorporeal membrane oxygenation (\%)
\end{tabular}

Table 5 - Predictors of mortality in COVID-19 patients.

\begin{tabular}{lccc}
\hline Predictors & OR & $\begin{array}{c}\text { 95\% CI } \\
\text { Lower - Upper }\end{array}$ & P-value \\
\hline $\begin{array}{l}\text { History of comorbidities } \\
\text { Obesity }\end{array}$ & 18.143 & $10.862-30.303$ & $0.001^{*}$ \\
$\quad$ Smoker & 7.018 & $4.398-11.199$ & $0.001^{*}$ \\
$\quad \begin{array}{l}\text { Diabetes mellitus } \\
\text { Complications }\end{array}$ & 3.007 & $1.867-4.844$ & $0.001^{*}$ \\
$\begin{array}{l}\text { Respiratory failure } \\
\text { Acute kidney injury }\end{array}$ & 95.772 & $42.663-214.993$ & $0.001^{*}$ \\
$\begin{array}{l}\text { Septic shock } \\
\text { Acute respiratory }\end{array}$ & 41.980 & $22.325-78.938$ & $0.001^{*}$ \\
distress syndrome & 15.310 & $8.437-27.783$ & $0.001^{*}$ \\
\hline
\end{tabular}

P-value calculated depend on logistic regression analysis. ${ }^{*}$ p-value $<0.05$ is significant. OR: odd ratio, CI: confidence interval

Cardiovascular disease (ACS, decompensated heart failure, dysrhythmias, and myocarditis) was reported in $10 \%$ of our patients and may have had a negative impact on prognoses and outcomes due to resultant myocardial injuries. ${ }^{28,29}$ Differentiation between cardiac versus respiratory etiologies may be difficult for COVID-19 patients presenting with dyspnea or chest pain; however, recognizing the combined cardiovascular and pulmonary pathologies for this disease is critical for its management and prognosis. ${ }^{30}$

Although previous studies have illustrated the importance of clinical characteristics and the presence of risk factors in ICU-admitted patients, ${ }^{31,32}$ our study provides more comprehensive data regarding predictors for ICU admission and death in severely ill patients. The major predictors were advanced age, male gender, and the co-existence of multiple comorbidities. The latter has been shown to be linked to rapid progression of the disease and a higher risk for developing multi-organ failure and ARDS, which might require prolonged hospitalization and extensive support with ECMO. 33,34

Laboratory investigations are also vitally important for the assessment of disease severity, and to guide disease management. Low hemoglobin levels, low platelet counts, prolonged INR levels, elevated cardiac enzymes, D-dimer levels, renal-function tests, and liverfunction tests have all been reported as indicators for poor outcomes. ${ }^{35,36}$

Approximately $4.3 \%$ of the patients evaluated in this study died. Most deaths were due to ARDS and respiratory failure, and a previous study showed that ARDS was responsible for $53 \%$ of total COVID-19 deaths. ${ }^{37}$ The clinical implication for this study is that it provides insight for the major death and ICU admission predictors among COVID-19 patients in Saudi Arabia. This may help treating physicians to better triage patients and subsequently prioritize ICU admissions by identifying high-risk medical and clinical indicators.

Study limitations. First, although we obtained data from 768 patients in Saudi Arabia with laboratoryconfirmed COVID-19, the analysis is based on a single center. More patients will be needed from other centers to provide more generalizable data. Second, we have reported baseline results from patients upon hospital admission; data from patients in home isolation or at hotels were not easily obtained.

In conclusion, despite these constraints, our data provides evidence that COVID-19 affects a wide variety of people, fever was consistently the most common early symptom, and both diabetes and hypertension were the most associated comorbidities. Certain patients with COVID-19, particularly smokers, obese or those who have history of lung disease, were in a critical risk of ICU admission. In high-risk populations, infection with SARS-Cov-2 can induce both systemic and pulmonary inflammation, leading to multiple organ dysfunction. Added to respiratory failure and acute respiratory distress syndrome, acute kidney injury and septic shock 
may also contribute to the critical illness state associated with high mortality. Fatality rate was $4.3 \%$. Obesity, smoking, and diabetes mellitus were predictors of death in COVID-19 positive patients.

Acknowledgment. The authors gratefully acknowledge Cambridge Proofreading LLC for English language editing.

\section{References}

1. Song W, Gui M, Wang X, Xiang Y. Cryo-EM structure of the SARS coronavirus spike glycoprotein in complex with its host cell receptor ACE2. PLoS Pathog 2018; 14: e1007236.

2. Wu Y, Chen C, Chan Y. The outbreak of COVID-19: An overview. J Chin Med Assoc 2020; 83: 217-20.

3. Cucinotta D, Vanelli M. WHO declares COVID-19 a pandemic. Acta Biomed 2020; 91: 157-160.

4. Sohrabi C, Alsafi Z, O’Neill N, Khan M, Kerwan A, Al-Jabir A, et al. World Health Organization declares global emergency: A review of the 2019 novel coronavirus (COVID-19). Int J Surg 2020; 76: 71-76.

5. Perlman S. Another Decade, another coronavirus. N EnglJ Med 2020; 382: 760-762.

6. Haleem A, Javaid M, Vaishya R, Deshmukh SG. Areas of academic research with the impact of COVID-19. Am J Emerg Med 2020; 38: 1524-1526.

7. Petrosillo N, Viceconte G, Ergonul O, Ippolito G, Petersen E. COVID-19, SARS and MERS: are they closely related? Clin Microbiol Infect 2020; 26: 729-734.

8. Xu X, Chen P, Wang J, Feng J, Zhou H, Li X et al. Evolution of the novel coronavirus from the ongoing Wuhan outbreak and modeling of its spike protein for risk of human transmission. Sci China Life Sci 2020; 63: 457-460.

9. REUTERS. Saudi Arabia announces first case of coronavirus. [Updated 2020 March 2; Accessed 2020 August]. Available form URL: https://www. reuters.com/article/us-healthcoronavirus-saudi/saudi-arabia-announcesfirst-case-ofcoronavirus-idUSKBN20P2FK

10. Yang J, Zheng Y, Gou X, Pu K, Chen Z, Guo Q et al. Prevalence of comorbidities and its effects in patients infected with SARS-CoV-2: a systematic review and meta-analysis. Int J Infect Dis 2020; 94: 91-95.

11. Chen T, Wu D, Chen H, Yan W, Yang D, Chen G et al. Clinical characteristics of 113 deceased patients with coronavirus disease 2019: retrospective study. BMJ 2020; 368: m1091.

12. Arentz M, Yim E, Klaff L, Lokhandwala S, Riedo F, Chong M et al. Characteristics and outcomes of 21 critically Ill patients with COVID-19 in Washington State. JAMA 2020; 323: 1612-1614.

13. Huang C, Wang Y, Li X, Ren L, Zhao J, Hu Y, et al. Clinical features of patients infected with 2019 novel coronavirus in Wuhan, China. Lancet 2020; 395: 497-506.

14. Guan W, Ni Z, Hu Y, Liang W, Ou C, He J, et al. Clinical Characteristics of Coronavirus Disease 2019 in China. N EnglJ Med 2020; 382: 1708-1720.

15. Huang X, Wei F, Hu L, Wen L, Chen K. Epidemiology and clinical characteristics of COVID-19. Arch Iran Med 2020; 23: 268-271.
16. Saudi Center for Disease Prevention Control, Ministry of Health Saudi. Novel Corona Virus (2019-nCoV) Infection Guidelines V1.0. [Update January 2020; Accessed 2020 August]. Available from URL: https://www.moh.gov.sa/en/ CCC/healthp/regulations/Documents/Novel\%20Corona\%20 Virus\%20Infection\%20Guidelines.pdf

17. Tian S, Hu N, Lou J, Chen K, Kang X, Xiang Z, et al. Characteristics of COVID-19 infection in Beijing. J Infect 2020; 80: 401-406.

18. Zhu W, Xie K, Lu H, Xu L, Zhou S, Fang S. Initial clinical features of suspected coronavirus disease 2019 in two emergency departments outside of Hubei, China. J Med Virol 2020; 92: 1525-1532.

19. Chen N, Zhou M, Dong X, Qu J, Gong F, Han Y, et al. Epidemiological and clinical characteristics of 99 cases of 2019 novel coronavirus pneumonia in Wuhan, China: a descriptive study. Lancet 2020; 395: 507-513.

20. Oudit GY, Pfeffer MA. Plasma angiotensin-converting enzyme 2: novel biomarker in heart failure with implications for COVID-19. Eur Heart J 2020; 41: 1818-1820.

21. Zhou F, Yu T, Du R, Fan G, Liu Y, Liu Z, et al. Clinical course and risk factors for mortality of adult inpatients with COVID-19 in Wuhan, China: a retrospective cohort study. Lancet 2020; 395: 1054-1062.

22. Richardson S, Hirsch JS, Narasimhan M, Crawford JM, McGinn T, Davidson KW, et al. Presenting characteristics, comorbidities, and outcomes among 5700 patients hospitalized with COVID-19 in the New York City Area. JAMA 2020; 323: 2052-2059.

23. Kulcsar KA, Coleman CM, Beck SE, Frieman MB. Comorbid diabetes results in immune dysregulation and enhanced disease severity following MERS-CoV infection. JCI Insight 2019; 4: e131774.

24. Maddaloni E, Buzzetti R. Covid-19, and diabetes mellitus: unveiling the interaction of two pandemics. Diabetes Metab Res Rev 2020; e33213321.

25. Sun P, Qie S, Liu Z, Ren J, Li K, Xi J. Clinical characteristics of hospitalized patients with SARS-CoV-2 infection: A single arm meta-analysis. J Med Virol 2020; 92: 612-617.

26. Rodriguez-Morales AJ, Cardona-Ospina JA, Gutiérrez-Ocampo E, Villamizar-Peña R, Holguin-Rivera Y, Escalera-Antezana JP, et al. Clinical, laboratory and imaging features of COVID-19: A systematic review and meta-analysis. Travel Med Infect Dis 2020; 34: 101623.

27. Pan L, Mu M, Yang P, Sun Y, Wang R, Yan J, et al. Clinical Characteristics of COVID-19 Patients With Digestive Symptoms in Hubei, China. Am J Gastroenterol 2020; 115: 766-773.

28. Aghagoli G, Gallo Marin B, Soliman LB, Sellke FW. Cardiac involvement in COVID-19 patients: Risk factors, predictors, and complications: A review. J Card Surg 2020; 35: 1302-1305.

29. Lippi G, Plebani M. Laboratory abnormalities in patients with COVID-2019 infection. Clin Chem Lab Med 2020; 58 : 1131-1134.

30. Fried JA, Ramasubbu K, Bhatt R, Topkara VK, Clerkin KJ, Horn E, et al. The variety of cardiovascular presentations of COVID-19. Circulation 2020; 141: 1930-1936.

31. Wang Y, Lu X, Li Y, Chen H, Chen T, Su N, et al. Clinical course and outcomes of 344 intensive care patients with COVID-19. Am J Respir Crit Care Med 2020; 201:1430-1434. 
32. Guan WJ, Liang WH, Zhao Y, Liang HR, Chen ZS, Li YM, et al. Comorbidity and its impact on 1590 patients with COVID-19 in China: a nationwide analysis. Eur Respir J 2020; 55: 2000547.

33. Zaim S, Chong JH, Sankaranarayanan V, Harky A. COVID-19 and multiorgan response. Curr Probl Cardiol 2020; 45: 100618.

34. MacLaren G, Fisher D, Brodie D. Preparing for the most critically ill patients with COVID-19: The potential role of extracorporeal membrane oxygenation. JAMA 2020; 323: $1245-1246$.
35. Wang D, Hu B, Hu C, Zhu F, Liu X, Zhang J, et al. Clinical characteristics of 138 hospitalized patients with 2019 Novel Coronavirus-infected pneumonia in Wuhan, China. JAMA 2020; 323: 1061-1069.

36. Zhang G, Hu C, Luo L, Fang F, Chen Y, Li J, et al. Clinical features, and short-term outcomes of 221 patients with COVID-19 in Wuhan, China. J Clin Virol 2020; 127: 104364.

37. Ruan Q, Yang K, Wang W, Jiang L, Song J. Clinical predictors of mortality due to COVID-19 based on an analysis of data of 150 patients from Wuhan, China. Intensive Care Med 2020 05; $46: 846-848$. 